\title{
The Production of Opacity in Serum by Group A Streptococci and Its Relationship with the Presence of M Antigen
}

\author{
By JEAN P. WIDDOWSON, W. R. MAXTED AND DORIS L. GRANT \\ Cross-Infection Reference Laboratory, Central Public Health Laboratory, \\ Colindale Avenue, London, N.W. 9
}

(Accepted for publication I8 February 1970)

\begin{abstract}
SUMMARY
The ability to produce opacity in horse serum is a characteristic of certain $M$ types of group A streptococci. The types that produce the opacity factor ( $O$ factor) are generally those for which it is difficult to produce good anti$\mathbf{M}$ sera. $\mathbf{M}$-positive $(\mathbf{M}+)$ and true $\mathbf{M}$-negative $(\mathbf{M}-)$ variants of strains that belong to serotypes in which the serum opacity reaction (s.o.r.) is positive both possess the $\mathrm{O}$ factor, but there is a difference in binding of the factor to other cellular components in the two variants. The $O$ factor is closely bound to the wall-membrane fraction of $\mathbf{M}-$ cells, whereas in $\mathbf{M}+$ cells it is easily extracted by Lancefield's method or I \% sodium deoxycholate. It is detectable in broth culture supernatants, in the cytoplasm and in the areas surrounding colonies in pour plates of $\mathbf{M}+$ but not of $\mathbf{M}-$ cultures. The $\mathbf{O}$ factor is poorly antigenic, but when it is possible to obtain a good antiserum the inhibitory action is type specific. The $O$ factor produced by several $\mathbf{M}$ types appears to be inhibited by normal rabbit serum.
\end{abstract}

\section{INTRODUCTION}

The production of opacity in horse serum by group A streptococci is believed to be mediated by a lipoproteinase which acts upon the $\alpha_{1}$-lipoprotein fraction of the serum (Krumwiede, I954; Rowen \& Martin, 1963). Streptococci of groups other than A apparently do not produce opacity in serum, and within group A the serum opacity reaction (s.o.r.) is positive only in certain serotypes. Gooder (196I) and Köhler (1963) grew streptococci in a liquid medium consisting of 3 parts horse serum and I part Hartley digest broth, and recorded the presence of opacity in the culture supernatant as a positive s.o.r. Consistently s.o.r.-positive serotypes were those in which no $M$ antigen was detectable, or for which satisfactory anti-M sera were difficult to prepare; on the other hand, members of a number of easily recognizable $\mathbf{M}$ serotypes were almost invariably s.o.r.-negative. Both workers suggested that there was an inverse relationship between a positive s.o.r. and the production of $\mathbf{M}$ antigen. Top \& Wannamaker (I968a) incubated killed cells or deoxycholate extracts of fractions consisting predominantly of cell walls and cell membranes ('wall-membrane fractions') in horse serum. They confirmed that opacity was frequently produced by members of 'difficult' $M$ types, but could find no true inverse relationship between $M$ antigen and opacity production, except among type 12 strains.

Most of the evidence concerning the supposed inverse relationship was obtained by examining collections of $\mathbf{M}$-typable and $\mathbf{M}$-untypable strains with common $\mathbf{T}$-antigen 
patterns (Gooder, 196I; Top \& Wannamaker, I968a). Evidence based on the examination of $M+$ and $M-$ variants from the same culture appears to be lacking, except possibly in the case of type 12 strains.

We have now examined, by a variety of methods, the serum opacity reactions of paired $M+$ and $M-$ variants, each pair isolated from the same culture. The results indicate a different relationship between $M$ antigen and $O$ factor production from that suggested by previous workers. We have also obtained some information about the location within the streptococcal cell of the factor responsible for the production of opacity.

\section{METHODS}

Strains of group A streptococci were classified by $T$ typing (Griffith, 1934) and M typing (Swift, Wilson \& Lancefield, 1943). The strains in Table I were used for the selection of $M+$ and $M-$ variants. In addition, strains SF 59 (M type 2), R68/I II5 (M type 4), T9/IOI/4 (M type 9 ), T I I/54/4 (M type II), R68/3 I I6 (T type I2, M type 22), T22/83/2 (T type 22, M type 22), T25/PZH small (M type 25) and Lancefield's strain B 737/34/3 (M type 49) were used as vaccine strains for the production of antis.o.r. sera. Representatives of a variety of different serotypes, selected from stock laboratory strains and from cultures submitted for serotyping, were used in preliminary screening experiments.

Table I. Strains of group $A$ streptococci used in selection of $M+$ and $M-$ variants

\begin{tabular}{|c|}
\hline Strain number \\
\hline SF I3O/13 (NCTC 8198) \\
\hline $\begin{array}{l}\text { SF } 59 \\
\text { R } 68 / \text { IIIS }\end{array}$ \\
\hline $\begin{array}{l}\text { T5B/PS } \\
\text { T II } / 54 / 4 \\
\text { R } 60 / 2408\end{array}$ \\
\hline $\begin{array}{l}\text { R69/2408 } \\
\text { II } 30\end{array}$ \\
\hline $\begin{array}{l}\text { R 47/3722 (NCTC } 8300) \\
\text { R69/1804 } \\
\text { R } 69 / 1805 \\
\text { R } 69 / 3116\end{array}$ \\
\hline A 703 \\
\hline
\end{tabular}

$\begin{array}{cc}\text { T agglutination } \\ \text { pattern } & \text { M type } \\ \text { I } & \text { I } \\ 2 & 2 \\ 4 & 4 \\ 5 & 5 \\ \text { II } & \text { II } \\ \text { I1 } & \text { II } \\ \text { I2 } & \text { I2 } \\ \text { I2 } & \text { I2 } \\ 22 & 22 \\ \text { 22 } & 22 \\ \text { I2 } & 22 \\ \text { 49 (I4) } & 49 \\ \text { 3/13/B 3264 } & \text { NT }\end{array}$

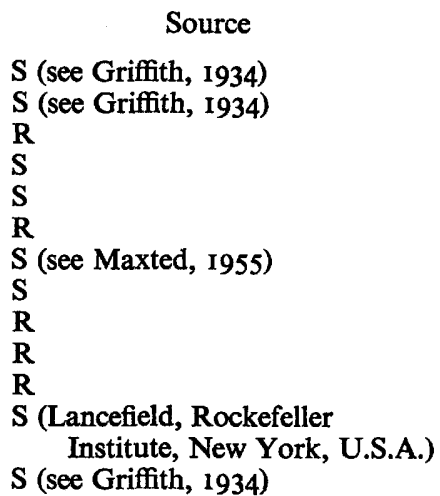

$\mathrm{S}=$ Colindale stock strain; $\mathrm{R}=$ strain received for routine typing; $\mathrm{NT}=$ not typable.

Selection of $M+$ and $M-$ variants. Colonies of virulent group A streptococci often have a typically 'matt' appearance on blood agar. Loss of $M$ antigen, associated with loss of virulence, is often accompanied by a change to the 'glossy' colonial form (Lancefield \& Todd, 1928). For the selection of variants, cultures were streaked on plates of Hartley Digest agar (Burroughs Wellcome \& Co., London N.W.I) containing $5 \%(\mathrm{v} / \mathrm{v})$ horse blood, incubated at $37^{\circ}$ for $24 \mathrm{hr}$ and then examined for differences in colonial morphology. Most of the strains used were matt initially, but it was possible in some to detect occasional glossy variants. The majority of the strains 
chosen for investigation (Table I) were ones in which it appeared relatively easy to do this but many of the strains examined in preliminary experiments did not produce glossy variants even on repeated subculture. Some strains were examined on serum glucose agar (Hartley Digest agar $+5 \%(\mathrm{v} / \mathrm{v})$ horse serum $+0.2 \%(\mathrm{w} / \mathrm{v})$ glucose). A few variants were picked by their 'opaque' $(M+)$ or 'blue' $(M-)$ appearance on this medium. The selected pairs of variants of each strain were retyped by T-agglutination and M-precipitin tests to establish that they shared a common $T$ pattern and that the glossy variant lacked the appropriate $M$ antigen.

Survival in human blood. $\mathbf{M}+$ and $\mathbf{M}-$ variants were examined for their ability to survive and multiply in human blood. Heparinized samples of normal blood were obtained from at least three individuals, and the tests were carried out as described by Maxted \& Valkenburg (1969). A $4 \mathrm{hr}$ culture of organisms in Todd-Hewitt broth was diluted so that $0.02 \mathrm{ml}$. contained Ioo to 200 colony-forming units. This volume was inoculated into $0.3 \mathrm{ml}$. blood in an ampoule, which was sealed and rotated slowly for 3 to $4 \mathrm{hr}$ at $37^{\circ} ; 0.02 \mathrm{ml}$. samples were then withdrawn from the ampoule and spread on the surface of blood agar plates. The plates were incubated at $37^{\circ}$ for $24 \mathrm{hr}$ and the extent of survival or growth scored on a scale: -(no colonies) to $4+$ (confluent growth).

\section{Preparation of fractions for use in s.o.r. tests}

Washed cells. In screening experiments, in which large numbers of strains were examined, strains were grown overnight at $37^{\circ}$ in $3 \mathrm{ml}$. Todd-Hewitt broth (Oxoid Todd-Hewitt broth + I \% (w/v) Neopeptone (Difco Ltd., Detroit, Michigan, U.S.A.). The bacteria were deposited by centrifugation and washed once in normal saline. In all other experiments involving washed cells, standardized suspensions of cells were prepared by suspending the washed growth from $50 \mathrm{ml}$. of a $24 \mathrm{hr}$ culture to an extinction $(A)=\mathrm{I} \cdot 0$ at $600 \mathrm{~nm}$. (Unicam SP600 spectrophotometer) in normal saline containing $\mathrm{I}$ in $5000(\mathrm{w} / \mathrm{v})$ thiomersal.

Supernatant fluids. These were obtained by centrifugation of overnight cultures in Todd-Hewitt broth.

Lancefield extracts. $\mathrm{N} / 5$ hydrochloric acid extracts were prepared from the overnight growth in $50 \mathrm{ml}$. Todd-Hewitt broth by the method described by Swift et al. (I943).

Deoxycholate extracts. Wall-membrane fractions were extracted with $\mathrm{I} \%$ sodium deoxycholate for $16 \mathrm{hr}$ at $4^{\circ}$ (Top \& Wannamaker, $1968 \mathrm{~b}$ ).

Wall-membrane fractions. Washed cells were disrupted in a Mickle disintegrator at $4^{\circ}$ (Michel \& Gooder, 1962). Centrifugation at $20,000 \mathrm{~g}$ for I hr sedimented the wallmembrane fraction. After two washings in normal saline the opacity of the suspension in saline was adjusted to $A_{600}=\mathrm{I} \cdot 0$.

Cytoplasmic fractions were obtained as the supernatant fluids from the first highspeed centrifugation of the Mickle-disintegrated material.

\section{Serum opacity reactions with cell fractions and extracts}

The s.o.r. of cell fractions and extracts were tested by incubating $0.2 \mathrm{ml}$. material with $\mathrm{I} \cdot 0 \mathrm{ml}$. horse serum (Wellcome Research Laboratories, Beckenham, Kent) containing $\mathrm{I}$ in $5000(\mathrm{w} / \mathrm{v})$ thiomersal, for 16 to $\mathrm{I} 8 \mathrm{hr}$ at $37^{\circ}$. After incubation, $\mathrm{I} \cdot 2 \mathrm{ml}$. saline was added to each tube and the extinction read in a Unicam SP60o spectrophotometer at $475 \mathrm{~nm}$. No increase in opacity compared with the control (I*4 ml. 
saline $+\mathrm{I} \cdot 0 \mathrm{ml}$. horse serum) was recorded as a negative s.o.r. An increase of up to 0.05 was recorded as, \pm 0.05 to 0.20 as $I+, 0.20$ to 0.30 as $2+$, an increase of greater than 0.30 as a $3+$ reaction. In screening tests for the s.o.r. of whole cells, the washed cell pellet from $3 \mathrm{ml}$. of a $24 \mathrm{hr}$ culture was suspended in $\mathrm{I} \cdot 0 \mathrm{ml}$. of horse serum containing $\mathrm{I}$ in $5000(\mathrm{w} / \mathrm{v})$ thiomersal, and the opacity developed after 16 to $18 \mathrm{hr}$ at $37^{\circ}$ was graded by eye from - (no opacity) to $3+$ (very opaque). All tubes were centrifuged at $2500 \mathrm{~g}$ for $\mathrm{I0}$ min. to remove particulate matter before opacities were read.

\section{Serum opacity reactions of growing cultures}

In serum broth (Gooder, 1961). One loopful of an overnight Todd-Hewitt broth culture was transferred to $3 \mathrm{ml}$. of serum broth (I part Hartley pancreatic digest of beef +3 parts horse serum) and incubated at $37^{\circ}$ for 18 to $24 \mathrm{hr}$. Tubes were read at $475 \mathrm{~nm}$, and an increase in extinction up to 0.1 was recorded as a \pm s.o.r., 0.1 to 0.25 as $\mathrm{I}+, 0.25$ to 0.45 as $2+$, and greater than 0.45 as $3+$. No increase in extinction of the medium was recorded as a negative s.o.r.

In pour-plates. A method similar to that of Maxted \& Valkenburg (1969) was used, except that Oxoid Ion agar no. 2 replaced Davis agar; I \% (w/v) of this in a mixture of equal parts of Wright broth (Mackie \& McCartney, 1960) and horse serum gave a clear medium in which zones of opacity around colonies were easily visible. Plates were incubated at $37^{\circ}$ for $48 \mathrm{hr}$ and then allowed to remain at room temperature for 24 to $48 \mathrm{hr}$ before reading.

\section{Preparation of protoplast membranes by means of phage-associated lysin}

Protoplasts were induced by incubating washed streptococci in a mixture of equal parts of reduced phage-associated lysin and $4 \mathrm{M}$-sodium chloride for $30 \mathrm{~min}$. at $37^{\circ}$, as described by Gooder \& Maxted (1958). The mixture was centrifuged at $3500 \mathrm{~g}$ for $15 \mathrm{~min}$. and the supernatant fluid kept for s.o.r. testing. The protoplast pellet was suspended in distilled water and the lysed protoplast envelopes were sedimented at $20,000 \mathrm{~g}$ for $60 \mathrm{~min}$. The supernatant fluid (cytoplasm) was also kept for the s.o.r. test. The protoplast envelopes were washed twice in water before testing for s.o.r.

\section{Preparation of antisera against the opacity factor}

Wall-membrane fractions were given intravenously to rabbits as described by Top \& Wannamaker (I968b). Two rabbits were inoculated with each strain. They were bled after a series of $3 \times 1 \cdot 0 \mathrm{ml}$. injections per week given over a period of 5 weeks, and their sera were tested for inhibitory activity against the $O$ factor of the vaccine strain. When this was present, the rabbits received $\mathrm{I} \cdot 0 \mathrm{ml}$. injections of vaccine weekly for a further 4 weeks to maintain the increased antibody level. When the s.o.r.inhibiting capacity was low or absent at the first bleeding $3 \times 1 \cdot 0 \mathrm{ml}$. injections per week were given during this 4 -week period. Pre-immunization serum was obtained from all rabbits for use as controls in inhibition tests.

Measurement of the inhibition of s.o.r. by antisera. The method used was similar to that of Top \& Wannamaker (I968b);0.2 ml. quantities of standardized $\left(A_{600}=\mathrm{I} \cdot 0\right)$ cell suspensions were pre-incubated for $15 \mathrm{~min}$. at $37^{\circ}$ with $0.2 \mathrm{ml}$. quantities of the antiserum before the addition of $\mathrm{I} \mathrm{ml}$. horse serum containing $\mathrm{I}$ in $5000(\mathrm{w} / \mathrm{v})$ thiomersal. After incubation at $37^{\circ}$ for 16 to $\mathrm{I} 8 \mathrm{hr}, \mathrm{I} \cdot 4 \mathrm{ml}$. saline was added to each tube and the $A_{475}$ was read spectrophotometrically. Two controls were set up for each 
strain, one containing $0.2 \mathrm{ml}$. normal rabbit serum, and the other $0.2 \mathrm{ml}$. normal saline in place of immune serum. A saline control was necessary to assess the extent of inhibition of opacity by normal rabbit serum. Blanks containing $0.2 \mathrm{ml}$. saline in place of the cell suspensions were set up for each serum used.

In inhibition tests involving material other than whole cells, e.g. cell fractions, supernatant fluids or extracts, $0.2 \mathrm{ml}$. samples of the materials were incubated with $0.2 \mathrm{ml}$. rabbit serum, and the test was done exactly as described for whole cells.

\section{RESULTS}

Preliminary examination of a large number of laboratory stock strains and strains received for routine typing revealed a distinct association between $\mathbf{M}$ type and ability to give a positive s.o.r. Our findings were in general agreement with those of Gooder (I96I) and Top \& Wannamaker (I968 a). M serotypes could be divided into two main groups with respect to their s.o.r.: the first group included $M$ types 2, 4, 9, II, I3, 22, $25,28,48$ and 49 , which were invariably s.o.r.-positive; the second, much larger group included the majority of other $M$ types, which were never s.o.r.-positive. We selected representatives from both groups for further investigation, and from some of the strains were able to pick $\mathbf{M}+$ and $\mathbf{M}-$ variants. It was important at this stage to establish, by the blood survival test, that the supposed $\mathbf{M}$ - variants selected from initially $\mathbf{M}+$ cultures were indeed truly $\mathbf{M}$ - versions of the original strain, and not strains with different $M$ antigens (Maxted \& Valkenburg, 1969).

Ability of $M+$ and $M-$ variants to survive in human blood. All $\mathrm{M}+$ variants gave $3+$ or $4+$ survival in the blood of at least three persons known not to possess antibody to the serotype under test. $\mathbf{M}$ - variants were killed, or at least prevented from multiplying during $4 \mathrm{hr}$ incubation, in normal human blood ( - , \pm , or I + survival). Presumed $\mathbf{M}+$ and $\mathbf{M}$ - variants that did not satisfy these criteria were rejected.

\section{Serum opacity reaction of $M+$ and $M-$ variants}

M+ and $\mathbf{M}-$ variants of strains belonging to both the s.o.r.-positive and s.o.r.negative groups of serotypes were examined in detail for ability to produce serum opacity. Preliminary investigations showed that when cell suspensions in which multiplication was prevented by the addition of $I$ in $5000(w / v)$ thiomersal were incubated in undiluted horse serum, both variants of a particular strain were either s.o.r.-positive or s.o.r.-negative, depending on the serotype. However, tests in serum pour-plates showed a striking difference between the $\mathrm{M}+$ and $\mathrm{M}-$ variants of the s.o.r.-positive group of strains. $M+$ variants in each case gave in pour-plates diffuse zones of opacity around the colonies. These zones had a characteristic appearance and seemed to flow to one side of the colony (Pl. I, fig. I). In some strains, e.g. members of types 9, II and I3, M+ colonies were surrounded by a defined opaque ring in addition to the more diffuse zone of opacity we associate with s.o.r. (Pl. I, fig. 2). Certain strains belonging to the group of serotypes that were never s.o.r.-positive also had these defined rings but never showed the more diffuse type of opacity (Pl. I, fig. 3). It was concluded that the presence of a defined opaque ring round colonies in serum pourplates was not associated with the serum opacity reaction. Strains that produced these rings were invariably mucoid, and the addition of hyaluronidase to the medium 


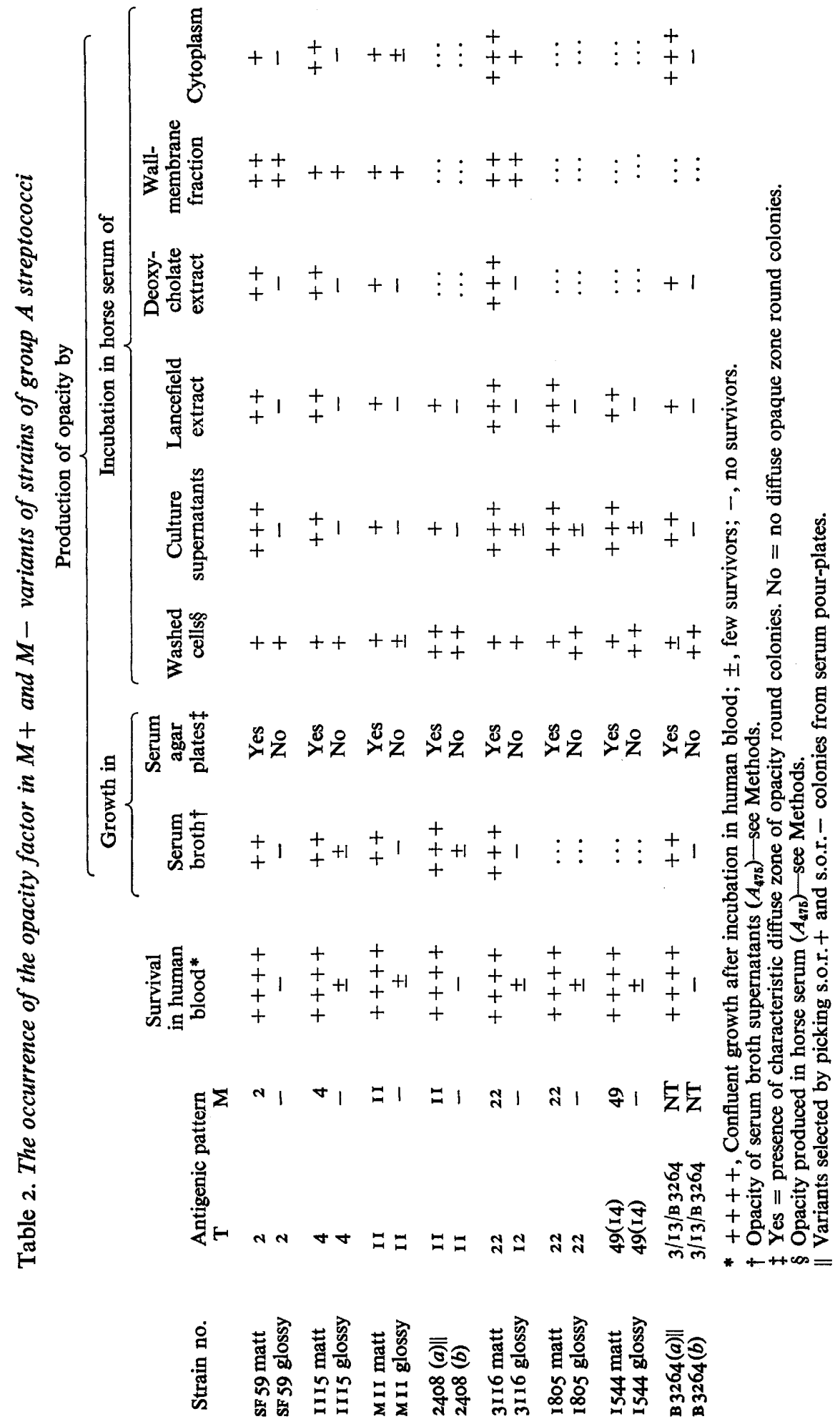


appeared to decrease ring formation in some cases, though this was by no means a consistent finding.

The difference between $\mathrm{M}+$ and $\mathrm{M}-$ variants with respect to ability to produce zones of opacity in serum agar plates prompted us to investigate other methods of detecting the opacity factor and to look for activity in different extracts and subcellular fractions of $\mathrm{M}+$ and $\mathrm{M}$ - variants. Table 2 shows the results of an investigation of the behaviour of four sets of paired variants of different s.o.r.-positive serotypes. Also included in Table 2 are the results of a smaller series of tests with other paired variants. The results showed striking differences between $M+$ and $M-$ variants in all of the pairs tested. The $\mathrm{O}$ factor was detectable in Lancefield extracts and I \% sodium deoxycholate extracts of $\mathbf{M}+$, but not of $\mathbf{M}-$ cultures. The culture supernatant fluids of $\mathbf{M}+$ cultures and of the cytoplasm of disrupted $\mathbf{M}+$ cells were invariably s.o.r.-positive; on the other hand, the $O$ factor was not detected in the culture supernatant fluids nor in the cytoplasm of $\mathrm{M}$ - cells. When the $\mathrm{O}$ factor was tested for in growing cultures, i.e. in serum pour-plates or in a liquid medium containing $75 \%$ (v/v) horse serum, only $M+$ cultures produced the opacity factor. However, it was clear from tests in which whole cells or wall-membrane fractions were incubated in horse serum that both $\mathbf{M}+$ and $\mathbf{M}-$ variants possessed $\mathrm{O}$ factor, since both gave a positive s.o.r. under these conditions. Therefore the difference between $M+$ and $M-$ variants appeared to be a difference in binding of the opacity factor to other cellular components. We also tested for the $\mathrm{O}$ factor in paired $\mathbf{M}+$ and $\mathbf{M}-$ variants of strains belonging to the group of $M$ serotypes that we had found in preliminary screening tests to be s.o.r.-negative (e.g. types $1,12,5$ ). The $O$ factor was completely absent from both variants of these strains, irrespective of the method of testing.

\section{Location of the opacity-producing factor}

Investigations were made to locate the opacity factor in $M+$ and $M-$ cells by preparing protoplast envelopes of both variants of a type 2 strain, and testing at various stages of preparation for the opacity factor. The results are summarized in Table 3. Most of the activity in $M$ - cells appeared to be bound to the cell membrane. The $O$ factor was also found in fractions containing cell wall fragments, but

Table 3. Location of the opacity factor in $M+$ and $M-$ variants of strain SF 59 Type 2

Fraction

Washed whole cells

Culture supernatant fluid

Supernatant fluid after lysin treatment

(contains cell wall fragments)

Supernatant fluid from lysed protoplasts (cytoplasm)

Protoplast membranes (unwashed)

Protoplast membranes (washed)

Washings from protoplast membranes

*Opacity produced in horse serum by

$\begin{array}{cc}\text { M+ variant } & \mathbf{M - \text { variant }} \\ + & + \\ +++ & - \\ ++ & + \\ ++ & - \\ + & ++ \\ + & ++ \\ ++ & -\end{array}$

\footnotetext{
* Opacity produced in horse serum $\left(A_{475}\right) ;-$, no increase in opacity; \pm increase of up to 0.05 ; + , increase of 0.05 to $0.2 ;++$, increase of 0.2 to $0.3 ;+++$ increase of greater than 0.3 .
} 
cytoplasmic constituents and washings from the protoplast membrane fraction were s.o.r.-negative. Although washed protoplast envelopes of $\mathbf{M}+$ cells had some s.o.r. activity, the greater activity of supernatant fluids, cell wall fragments and washings at every stage during the preparation showed that $O$ factor was easily removed from the cell membrane of $M+$ cells. Matt and glossy variants of other s.o.r.-positive serotypes behaved in a similar manner.

Table 4. Inhibition of the opacity factor by rabbit sera in washed cell suspensions of group $A$ streptococci

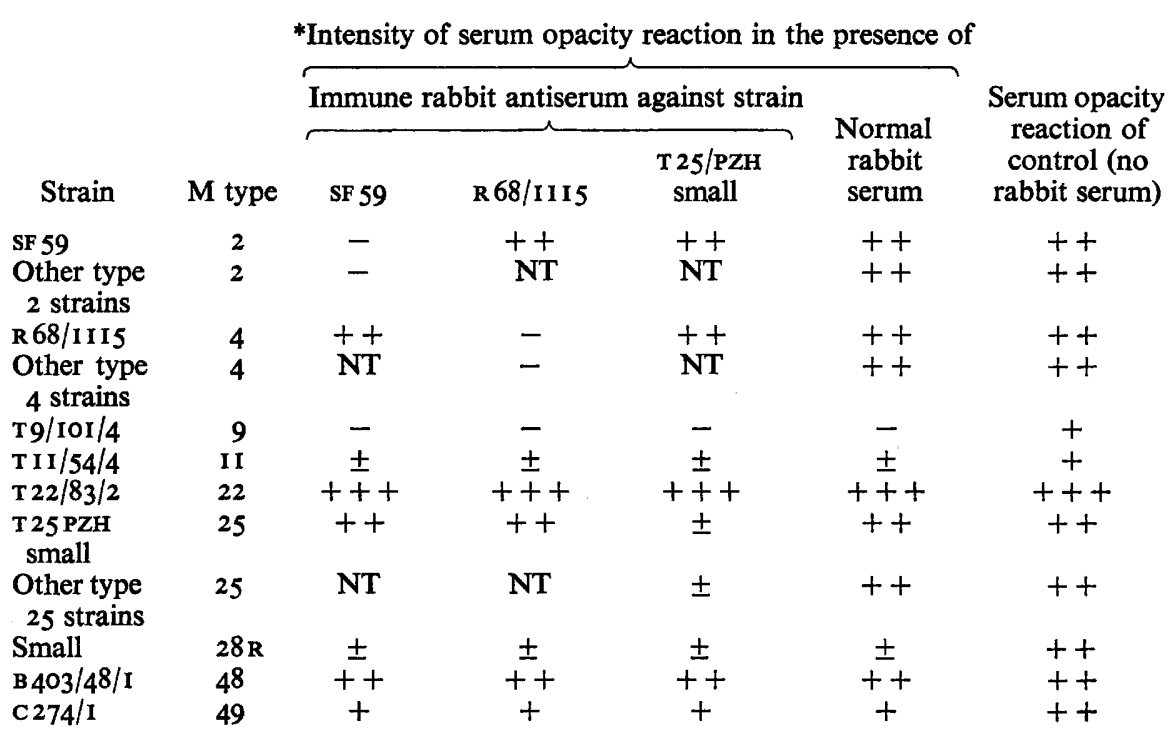

* Opacity produced in horse serum $\left(A_{475}\right)$; - , no increase in opacity; \pm , increase of up to 0.05 ; + increase of 0.05 to $0.2 ;++$, increase of 0.2 to $0.3 ;+++$; increase of $>0.3 ; \mathrm{NT}$, not tested.

\section{Inhibition of serum opacity reaction by type specific antisera}

Eight different vaccine strains were used in attempts to prepare anti-s.o.r. sera in rabbits. Three strains, i.e. R68/I I I 5 (type $4 \mathrm{M}+$ ), SF 59 (type $2 \mathrm{M}+$ ) and PZH (type $25 \mathrm{M}+$ ), gave sera capable of inhibiting the $O$ factor of the vaccine strain; we were unsuccessful in preparing antisera for the other five strains tested. The antisera that showed some activity (two type 4 sera, one type 2 serum, one type 25 serum) were each tested against several strains of the vaccine type and nine different s.o.r.-positive heterologous types. Washed cell suspensions $\left(A_{600}=I\right)$ were used as sources of opacity factor, and $0.2 \mathrm{ml}$. quantities were pre-incubated with the antiserum under test before the addition of horse serum (see Methods). Tubes were read at $475 \mathrm{~nm}$. on a Unicam SP60o. In each case inhibition seemed to be specific for the vaccine type, except that all rabbit sera tested (including normal rabbit sera) inhibited the s.o.r. of types 9, II, $28 \mathrm{R}, 49$ to a greater or lesser extent (Table 4 ). Inhibition by normal rabbit serum appeared to be a constant feature of the s.o.r. of these types. All samples of normal rabbit serum tested were inhibitory; the inhibition was most marked with type 9 , where the s.o.r. could virtually be eliminated by adding $0.2 \mathrm{ml}$. normal rabbit serum. 


\section{Inhibition of serum opacity reaction by antisera in $M+$ and $M-$ variants}

An antiserum prepared against the wall-membrane fraction of a type 4 matt variant was used to investigate the identity of the opacity factor of different fractions and extracts of $M+$ and $M$ - variants of strain R68/I I I5. These tests (Table 5) established that the $O$ factors detected in different fractions were antigenically identical, in that they were all inhibited by the specific antiserum. Plate I, fig. 4 shows the inhibition by specific antiserum of s.o.r. zones surrounding $M+$ colonies in serum pour-plates. The $O$ factor of the Lancefield extract of $M+$ cells seemed to be the exception in that it was inhibited only to a small and variable extent by the antiserum prepared against

Table 5. Inhibition, by specific antiserum, of the opacity factor in fractions and extracts of $M+$ and $M-$ variants of a type 4 strain

\begin{tabular}{|c|c|c|}
\hline \multirow[b]{2}{*}{ Source of opacity factor } & \multicolumn{2}{|c|}{$\begin{array}{l}\text { *Intensity of serum opacity reaction } \\
\text { in the presence of }\end{array}$} \\
\hline & $\begin{array}{l}\text { Normal rabbit } \\
\text { serum }\end{array}$ & Specific antiserum \\
\hline Washed $M+$ variant & ++ & - \\
\hline Washed $\mathbf{M}$ - variant & $+t$ & - \\
\hline $\begin{array}{l}\text { Culture supernatant fluid of } \mathrm{M}+ \\
\text { culture }\end{array}$ & +++ & - \\
\hline Lancefield extract of $\mathbf{M}+$ culture & +++ & ++ \\
\hline Deoxycholate extract of $\mathbf{M}+$ culture & +++ & \pm \\
\hline Wall-membrane fraction of $\mathrm{M}+$ & + & $\beth$ \\
\hline Wall-membrane fraction of $\mathbf{M}-$ & + & - \\
\hline Cytoplasm of $\mathbf{M}+$ & +++ & - \\
\hline $\begin{array}{l}\text { Colonies of } \mathbf{M}+\text { variant in serum } \\
\text { agar }\end{array}$ & Yest & No \\
\hline Culture of $M+$ variant in serum broth & +++ & - \\
\hline
\end{tabular}

* Increase in opacity of horse serum $\left(A_{475}\right)$; -, no increase in opacity; \pm , increase of less than 0.05 ; + , increase of 0.05 to $0.2 ;++$, increase of 0.2 to $0.3 ;+++$, increase of $>0.3$.

$\dagger$ Yes $=$ presence of diffuse zones of opacity around colonies. No $=$ no diffuse zones of opacity around colonies.

a type 4 wall-membrane vaccine. Extraction with more dilute acid $(\mathrm{N} / 20)$ or at lower temperature $\left(60^{\circ}\right)$ gave extracts in which the $O$ factor was inhibited by the specific antiserum. A specific antiserum prepared against the $O$ factor of the wall-membrane fraction of a type $2 M+$ variant gave similar results with the $O$ factor of $M+$ and $M-$ variants of a type 2 strain.

\section{DISCUSSION}

Gooder (1961) suggested that there was an inverse relationship between the production of opacity in serum and the presence of $M$ antigen. His evidence was a type I2 strain that was s.o.r.-negative when it was in the matt $(\mathrm{M}+)$ form and s.o.r.positive when it occurred as an apparently $M$ - variant. Our results with $M+$ and $M-$ variants of a variety of serotypes suggest a different relationship. Strains with the I2M antigen (T12, M I2) belong to the group of M types that are always s.o.r-negative; true $\mathbf{M}$ - variants of members of this group are also s.o.r.-negative. However, it is possible for type 12 strains to give variants that possess an $M$ antigen other than M I2 (Maxted \& Valkenburg, 1969, 1970, and to be published. Strains with these 
' $I 2$ variant' $M$ antigens are invariably s.o.r.-positive. The s.o.r. of type 12 and its variants will be discussed in detail elsewhere (Widdowson, Maxted \& Grant, 1970).

Both $\mathrm{M}+$ and $\mathrm{M}-$ variants of the s.o.r.-positive group of serotypes (e.g. types 2,4 , II , 22, 49) possess the opacity factor. This could be shown by incubating whole cells or wall-membrane fractions from $\mathbf{M}+$ and $\mathbf{M}-$ cultures in horse serum. However, other methods of testing for the $\mathrm{O}$ factor that were dependent on ease of extraction of the factor from cells, or its release into supernatant fluids during growth, gave s.o.rpositive results only with the $\mathrm{M}+$ variants. The site of binding of $\mathrm{O}$ factor in $\mathrm{M}-$ cells appeared to be on the cell membrane, though some activity was always present in the cell-wall fraction released by phage-associated lysin.

There is evidence that in s.o.r.-positive serotypes, $M$ antigen and the $O$ factor are closely associated chemically (J. P. Widdowson, W. R. Maxted \& D. L. Grant unpublished). Thus the presence of $O$ factor in the wall-membrane fraction of cells which had apparently lost the ability to produce $M$ antigen, raises the interesting possibility that $\mathrm{M}$ antigen itself might also be present in these cells in a bound or inactive form.

The studies of Top \& Wannamaker ( $1968 b$ ), showed the remarkable type specificity of the lipoproteinases of group A streptococci. They prepared antisera with specific inhibitory activity by the injection into rabbits of wall-membrane fractions of s.o.r.positive types. Twelve antigenically distinct lipoproteinases were identified in this way, though many of the strains tested did not give detectable amounts of antibody even after 9 weeks' immunization. In a limited series of experiments in which a similar method of immunization was used, we were able to prepare anti-s.o.r. sera to three strains out of eight tested. The anti-s.o.r. sera (against a type 4, a type 2 and a type 25 strain) were specific for the vaccine type, and to this extent our findings are in agreement with those of Top \& Wannamaker. With other vaccine strains (types 9, II, 49) the problem in assessing the anti-s.o.r. activity of the sera was that all normal rabbit sera tested gave some inhibition of opacity factor. The antigenicity of the $O$ factor of some types appears to be weak (in the vaccines we used) and the investigation of other types of vaccine seems warranted.

With the anti-s.o.r. serum prepared against strain R68/1II5 (type 4) it could be shown that the $O$ factor present in matt cells was antigenically identical with that in glossy cells. The $O$ factor detected in the culture supernatant fluids, in the cytoplasm and in deoxycholate extracts of matt cells was also inhibited by the specific antiserum. The $O$ factor in Lancefield extracts of $M+$ cultures was only partially inhibited by the antiserum. A possible explanation for this is that heating $\mathrm{M}+$ cells in the presence of acid may alter the structure of the $O$ factor so that, although it is still able to produce opacity in serum, it is unable to combine with its specific antibody. The fact that s.o.r.-positive Lancefield extracts were obtained only from s.o.r.-positive cells seems to indicate that the $O$ factor in these extracts is derived from the native form.

The detection of opacity in pour-plates of serum agar proved a useful means of distinguishing $\mathbf{M}+$ and $\mathbf{M}$ - variants of s.o.r.-positive serotypes. In our experience, colonies giving characteristic diffuse opaque zones in the surrounding medium are invariably found to be $\mathrm{M}+$ by survival tests in human blood, even when the lack of a suitable anti-M serum makes it impossible to demonstrate the $M$ antigen by the precipitin method. 
We are very grateful to Miss C. A. M. Fraser for supplying us with $\mathbf{M}$ and $\mathbf{T}$ typing sera.

\section{REFERENCES}

GoODER, H. (1961). Association of a serum opacity reaction with serological type in Streptococcus pyogenes. Journal of General Microbiology 25, 347-352.

GOODER, H. \& MAXTED, W. R. (1958). Protoplasts of group A $\beta$-haemolytic streptococci. Nature, London 182, 808-809.

GrIFFTH, F. (1934). The serological classification of Streptococcus pyogenes. Journal of Hygiene, Cambridge 34, 542-584.

KöHLER, W. (1963). Serum-Opazitäts-Reaktion (SOR) und die Bildung des M-antigens durch Streptococcus pyogenes. Zentralblatt für Bakteriologie, Parasitenkunde, Infektionskrankheiten und Hygiene (Abteilung I) r89, 275-28I.

KRUMWIEDE, E. (1954). Studies on a lipoproteinase of group A streptococci. Journal of Experimental Medicine 100, 629-639.

LANCEFIELD, R. C. \& TODD, E. W. (1928). Antigenic differences between matt hemolytic streptococci and their glossy variants. Journal of Experimental Medicine 48, 769-790.

Mackie \& McCartney's Handbook of Bacteriology. (1960). roth edn, p. 190. Edinburgh \& London: E. \& S. Livingstone.

MAXTED, W. R. (1955). The influence of bacteriophage on Streptococcus pyogenes. Journal of General Microbiology 12, 484-495.

MaXted, W. R. \& VAlKenburg, H. A. (1969). Variation in the M antigen of group A streptococci. Journal of Medical Microbiology 2, 199-210.

Maxted, W. R. \& VAlKenBURG, H. A. (1970). Variations in the M antigen of group A streptococci. Proceedings of the Fourth International Symposium on Streptococcus pyogenes, Jena, East Germany, 29 September-3 October 1969. (In preparation.)

Michel, M. F. \& Gooder, H. (I962). Amino acids, amino sugars and sugars present in the cell walls of some strains of Streptococcus pyogenes. Journal of General Microbiology 29, 199-205.

RowEN, R. \& MARTIN, J. (1963). Enhancement of cholesterol esterification in serum by an extract of a group A streptococcus. Biochimica et Biophysica Acta 70, 396-405.

Swift, H. F., Wilson, A. T. \& Lancefield, R. C. (1943). Typing group A hemolytic streptococci by $M$ precipitin reactions in capillary pipettes. Journal of Experimental Medicine 78, 127-133.

TOP, F. H. JUn. \& WANNAMAKER, L. W. (1968a). The serum opacity reaction of Streptococcus pyogenes: Frequency of production of streptococcal lipoproteinase by strains of different serological types and relationship to $M$ protein production. Journal of Hygiene, Cambridge 66, 49-58.

TOP, F. H. Jun. \& WANNAMAKER, L. W. (1968b). The serum opacity reaction of Streptococcus pyogenes. The demonstration of multiple strain specific lipoproteinase antigens. Journal of Experimental Medicine r27, ror3-1034.

Widdowson, J. P., MAXTED, W. R. \& Grant, D. L. (1970). The serum opacity reaction in group A streptococci. Proceedings of the Fourth International Symposium on Streptococcus pyogenes, Jena, East Germany, 29 September-3 October 1969. (In preparation.)

\section{EXPLANATION OF PLATE}

Fig. 1. Serum agar pour-plates of $(a) \mathrm{M}+$ and $(b) \mathrm{M}$ - variants of a type T $12 \mathrm{M} 22$ strain (R 69/31 16) of Streptococcus pyogenes.

Fig. 2. Colonies of a type II M+ strain ( $\mathrm{T}$ II/54/4) of Streptococcus pyogenes in a serum agar pourplate.

Fig. 3. Colonies of a type 24 (c98/97) M+ strain of Streptococcus pyogenes in a serum agar pour-plate.

Fig. 4. Colonies of a type $4 M+(R 68 / 1115)$ strain of Streptococcus pyogenes in serum agar pourplates $(a)$ in the presence of $\mathrm{I} \mathrm{ml}$. of normal rabbit serum per plate, $(b)$ in the presence of $1 \mathrm{ml}$. type specific anti-s.o.r. serum per plate. 

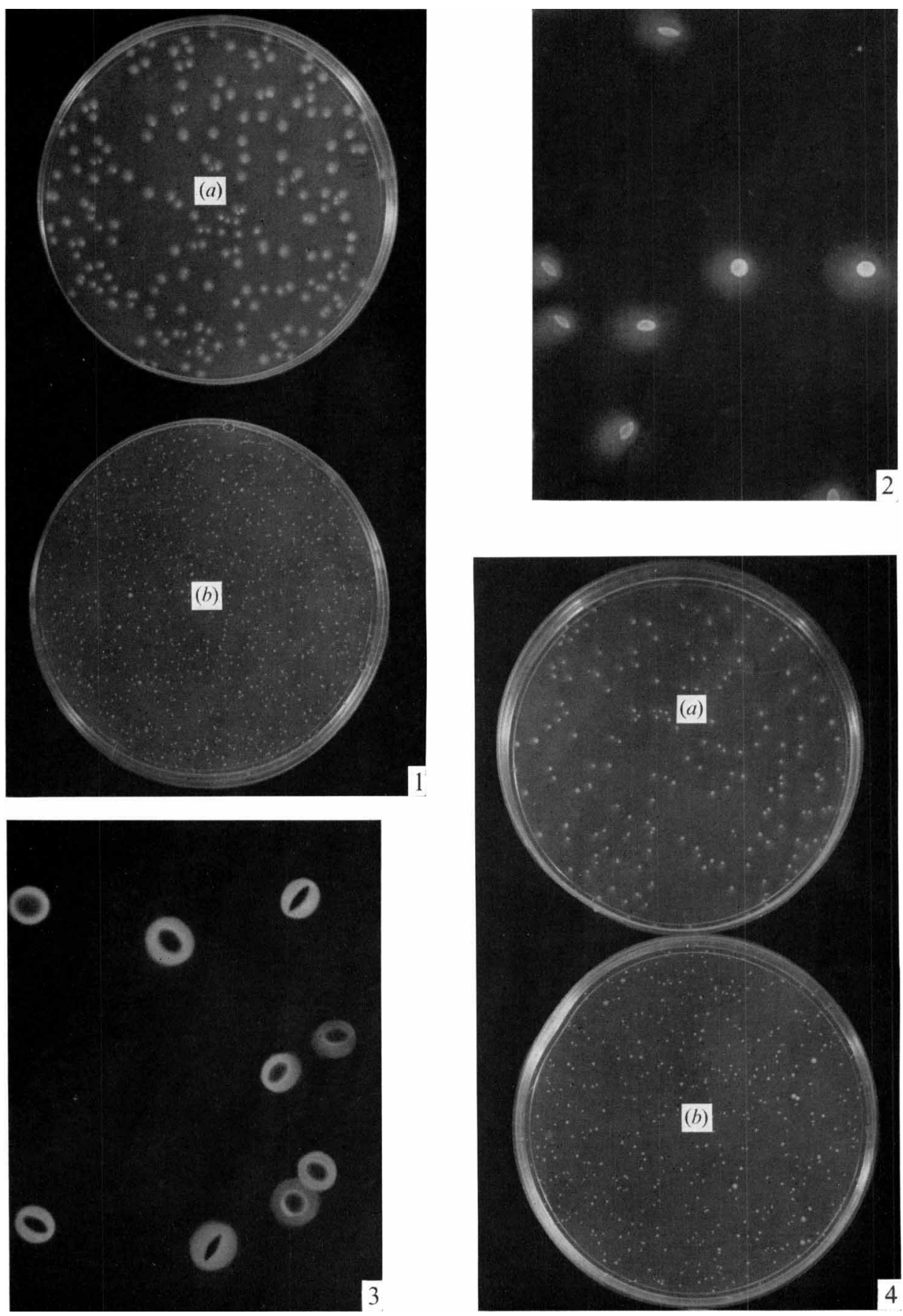